\title{
Declaratório do Humano Eticofágico
}

\author{
Cláudio de Morais Maia \\ Universidade Católica de Brasília (UCB)
}

Que é este ente, pois que se sente!

Que é este ente, pois que se cogita! ente?

Mas que é; se sente fome e sede? O que pode; se faminto e sedento? Que é este

Este diverso, que cheira, denteia, escuta, tateia, enxerga. Desenvolto, nas intempéries do tempo! Limitado, pelas arestas das áreas! Sôfrego, pelos contrastes tão próprios de sua multiplicidade naturalizada e não naturalística!

Que é este ditado ente - humano? Que é este negado ente - animália?

Se humano e animália, criado? Se animália e humano, surgido?

De Eros! De fago!

Tendo diviso, anima animus? Tendo diviso, kleitorís phallós?

E se, anima rija erétil phallós; e se ainda, animus rija erétil kleitorís?

Maldito diviso advindo, que tem fome e sede!

Mas que fome, que sede? Que come, que bebe para saciar? Comer e beber o quê?

Pois que, crista animália, de testa ossuda, donde nascem os lisos ou crespos pelos; que, por ânsia, são raspados, cortados, penteados, por quererem seduzir, tontear, sorver, sugar; já que, por inação ou repressão, dominam contendo a si - mutilam-se - imolamse - para não extravasarem, extrapolarem seu gosto tara, sua vontade fome, de subjulgar, devorar...

Pois que, loca humano de testa carnuda, donde nascem os lisos ou crespos pelos; que, por paixão, são raspados, cortados, penteados, por quererem seduzir, turvar, absorver, lamber, já que, por euforia ou tristeza, domina contendo a si - ilude-se engana-se - para extravasar, extrapolar seu gosto desejo, sua vontade apetite, de apropriar, introjetar...

Donde unificar o que é extrínseco no intrínseco, e o que é intrínseco no extrínseco! Tornar único em um todo o indissociável?

Pois que o extrínseco é do intrínseco, e o intrínseco é do extrínseco. E isto é pessoa.

Mas, este ente é diviso, eis porque baldeia, banqueteia, dia e noite, vezes e vezes! Mas jamais sacia. Mais, jamais faz conta. Mais, jamais faz juízo. Tudo lhe é comível, mas 
nada lhe sustenta, mesmo apesar de engolido, mesmo apesar de digerido, pois crê tudo sempre expelido, por juras mecânicas - vaporosos - suspiro e ventosidade - massivos excremento e fluido.

Disto que seu sentido e essência são comida! Que hora alimenta e nutre, causa saúde e vigor. Que hora exaure e desvitaliza, causa cólica e cólera.

Em ato: comem-se uns aos outros e uns e outros comem a si mesmos, disputam cada tico, cada bocado, de cada gomo, de cada gema, de cada bago. Não saciam.

Em corpus, kleitorís come phallós, phallós come kleitorís, kleitorís come kleitorís, phallós come phallós, plhallós come a si, kleitorís come a si; kleitorís não come; phallós não come; ambos morrem de fome!

Em daemon, anima come animus, animus come anima, anima come anima, animus come animus, animus come a si, anima come a si; anima não come; animus não come; ambos se extinguem!

Maldito diviso ente! Que sempre desesperado, lastima o universo, e nele avista paisagens, e pretende mundanas moralidades das quais se determina capaz para adotar, tamanha é sua gula e satisfação na comida.

Maldito diviso ente! Que sempre perplexo, contempla o etéreo, e nele avista miragens, e pretende divinas virtuosidades das quais se constrange incapaz para adotar, tamanha é sua gula e satisfação na comida.

E desta sua ambiguidade, motivada pela fome, é que assevera do seu corpus e do seu daemon; e por este tanto, desdenha de sua naturalidade e proclama sua naturalização. Funda, deste modo, sua religião. Erige em razão disto sua igreja, estabelecendo os dogmas do corpus e do daemon. Ao que, por saber ser o corpus quem come, faz deste o mecanismo de sua autossalvação e estatui que seja pela comida que sua vida tem sentido. E também por saber ser o daemon que sente fome, faz deste o mecanismo de sua perdição e estatui que seja pela fome que sua vida perde o sentido.

Mas de fundo sabe por si próprio ser corpus-daemon, não podendo, por aquela astúcia, salvar-se de si mesmo, "é um só todo" - animália-humanado - apesar de que negue que aquele que come é aquele que sente fome, pois, quem come, come porque sente fome, quem sente fome come; não há quem não sinta fome, todos têm fome, todos comem. E esta é a razão de não poder condenar e extirpar de si polarmente o daemon; apesar disto, permite-se ser cobiçoso, e por gana, quer necessário negá-lo; pois que assim pode prevalecer-se e desvincular-se de todos os outros seres que não lhe são semelhantes e presente existir, pois quer proteger-se da escassez de comida. Assim compreende quanto ao daemon, que deve apenas sublimá-lo e, para tanto, gera sua imagem diametralmente oposta, que não sente fome, que é per si plena e suficiente divina. E considera que, para poder relacionar-se com tal ente divinal, basta-lhe agora inspirar-se no divino, para que, por este meio, justifique sua comida! Eis que sacraliza o ente divinal personificando-o à sua própria semelhança, pois como negar o imaterial, se tal forma nos é reconhecível. Então é pela aparência que Deus é gerado, e nisto está implícito o vínculo entre o surgido e o criado, entre o existente e o antes não existente dando sentido à vida - de não sentir fome.

Assim, em sua astúcia, é que ousa crer-se refletido! Ousa mais ainda, e não admite mais ser animália, e crê ser apenas humanado - pois que deste modo jurígeno 
advém sua identidade sacralizada - verdade religiofágica - bendita unidade, que sagrada é legítima; e faz com que volte a ser uno - pessoa.

Pessoa que agora tem o poder, pois que reconhece a si mesma, por conhecer sua identidade, que sabe estar justificada, pois que o sentido de sua vida-existência é desenvolver-se a fim de suprimir a fome, o que o torna digno; noutra palavra, o faz ter o direito. E, para tanto, tem o direito de comer, para sobreviver, ou seja, não sucumbir à fome, tem o direito de evoluir, ou seja, deixar de ter fome; e com isso não é mais daemon e sim é spiritus.

Spiritus que atua no mundo em razão de sua natureza unificada; cuja força é saciedade, que é realizada no ato de comer, que ora passa a ser alimentação.

Deste modo, a alimentação é a forma purificada do sentido da vida que propicia à pessoa todos os meios de vivência e de vitalidade, e esses se tornam seus bens, o fim em si mesmo, o bem supremo! Esta é a sua política.

E é então para garantir sua saciedade que toda pessoa passa a legislar, construindo, tanto pela disputa quanto pelo acordo, o ordenamento legal que pacifica o valor do bem supremo, além de tudo aquilo que tende a este bem como útil, a fim de haver segurança e garantia de alimentação para todos aqueles que, por semelhança, se reconheçam como pessoas. Funda-se o governo cuja função é a produção de comida, e a responsabilidade é a divisão da comida produzida, sua garantia e segurança. Eis o modelo do humano eticofágico; a ideação daquele sentido estruturante com vistas a devir por medidas culturalistas segundo a moralis germe da respublica.

E que ao nosso tempo está perpetuado, pelo continuum - da gana perpassada no culturalismo enquanto perdura a natividade dos comíveis em razão da inexorável falência da pessoa humanada - pela morte de sua porção corpus; o que é economia.

Mas tamanha é sua gula e satisfação na comida que, sabendo sua porção spiritus - sagrada - em relação reflexiva com Deus - o divino refletivo, é que transcende a existência no mundo e assevera a imortalidade do spiritus, e assim protesta e faz persistir o seu direito à alimentação, visto não ser só corpus, mas também spiritus, ser corpus-spiritus; ao que, mesmo não podendo sorver por si mesmo, dada a morte daquele que come, o faz através de sua descendência, que herda o direito em consequente acumulação - eis o princípio da propriedade. Princípio que fecha a circunferência existencial do humanado; redundando na noção partidária e contraditória de família, uma aberração particularista.

Pois que o eticofágico é comedor, e tudo é comível, pois toda comida está a seu favor. E quando ademais algo esteja fora do seu alcance, o eticofágico deve mover-se a fim de apreendê-lo, de conquistá-lo, de tomá-lo, pois disto depende sua evolução, a prevalência de sua força, sua inequívoca nutrição, causa única de sua saúde e vigor.

Assim, comer é bem necessário, comer pelo cheiro a comida, comer pelo gosto a comida, comer pela beleza a comida, comer pela riqueza a comida. Comer pelo valor da comida, eis a sentença terminativa restritiva ao humanado. Além dessa, quem comer mais exaure a comida, se exaure na comida! Desvitaliza seu organismo pelo excesso que não pode processar, não pode consumir e não pode expelir, acumulando tudo que engole nas câmaras viscerais, nos mucos, nas cavas em meio às carnes, passando a sofrer das muitas cólicas que o fustigam, adoecem e matam. Torna-se bestial. 
Se por liberalidade a pessoa extravagante permite-se as muitas viciações da gula, ao que passa a ser fera devoradora - besta - que tudo quer engolir e expelir, nunca haverá de dominar-se, será sempre faminta e desejante, terminantemente não se salvará.

E disso provem toda impropriedade da viciação, que não resulta em nada de bom, que pelo excesso não é bem, e sim é mau - malefício.

Portanto, toda comida é um dom, virtude necessária à vida e à existência, que toda pessoa deve apreender em medida suficiente para a satisfação de suas porções animália e daemon-spiritus, nutrindo-as e vitalizando-as como condição primeira de sua existência e permanência neste mundo.

O cultivo dos comíveis, o cozer dos comíveis, e o bem comer-sorver são arte. Arte que garante uma boa vida. Uma vida virtuosa.

Assim, o ente eticofágico é pessoa - animália-humanada - que está no pleno domínio de seu corpus e daemon-spiritus, vivenciando e vivendo o bem comer-sorver segundo a virtuosidade do engolir, que é o seu sentido primeiro e a razão primordial. 